\title{
Analisis Penggunaan Obat Herbal Pada Pasien Diabetes Mellitus Di RSUD A.W Sjahranie Samarinda
}

\author{
Dewi Rahmawati ${ }^{1, *}$, Rina Fitriani ${ }^{2}$. \\ ${ }^{1}$ Laboratorium Pekerjaan Kefarmasian/PIO, Fakultas Farmasi, Universitas Mulawarman, \\ Samarinda, Kalimantan Timur \\ ${ }^{2}$ RSUD A.W Sjahranie, \\ Email: dewi@farmasi.unmul.ac.id
}

\begin{abstract}
ABSTRAK
Penggunaan obat herbal dan obat tradisional sebagai alternatif penyembuhan penyakit semakin meningkat di Indonesia karena sebagian besar masyarakat berpendapat bahwa hebal tidak mempunyai efek samping. Selama kurun waktu 2000-2006 terjadi peningkatan penggunaan obat tradisional, yang dilakukan untuk pengobatan sendiri (swamedikasi). Data yang diperoleh dari 15,2\% menjadi 38,30\%. Diabetes mellitus (DM) atau dikenal juga dengan sebutan penyakit kencing manis merupakan salah satu penyakit kronis. Pengobatan penyakit diabetes mellitus dilakukan secara terus-menerus untuk mengontrol kadar gula darahnya. Kondisi ini membuat pasien DM menjadi bosan untuk meminum obat. Pengobatan alternatif yang biasanya dilakukan oleh pasien DM adalah pemanfaatan obat herbal atau pengobatan tradisional. Penelitian ini bertujuan untuk mengetahui penggunaan obat herbal pada pasien diabetes mellitus. Penelitian yang dilakukan secara obeservasi. Pengambilan sampel dilakukan secara purposive sampling sebanyak 75 pasien. Dari hasil penelitian diperoleh data penggunan obat herbal atau obat tradisional pada pasien diabetes melittus sebanyak $62.32 \%$ sebagai obat komplementer. Jenis-jenis obat herbal atau obat tradisional yang digunakan adalah kulit manggis sebanyak 78,95\%, daun sirsak sebanyak $42,10 \%$, propolis sebanyak $7,89 \%$, brotowali sebanyak $2,63 \%$.
\end{abstract}

Kata kunci : obat tradisional, obat komplementer, pengobatan, diabetes mellitus

\section{PENDAHULUAN}

Penggunaan obat herbal dan obat tradisional sebagai alternatif penyembuhan penyakit semakin meningkat di Indonesia karena sebagian besar masyarakat berpendapat bahwa hebal tidak mempunyai efek samping. Selama kurun waktu 2000-2006 terjadi peningkatan penggunaan obat tradisional, yang dilakukan untuk pengobatan sendiri (swamedikasi). Data yang diperoleh dari $15,2 \%$ menjadi $38,30 \%$. Peningkatan ini terjadi mungkin disebabkan adanya intervensi pemerintah melalui promosi pemanfaatan obat asli Indonesia dan penggalakan TOGA (tanaman obat keluarga) atau mungkin juga berkaitan dengan peningkatan jumlah industr obat tradisional di Indonesia. Kegiatan swamedikasi biasanya kegiatan ini dilakukan untuk menangani penyakit-penyakit ringan, akan tetapi tidak menutup kemungkinan swamedikasi menggunakan obat herbal/obat tradisional dilakukan pada pasien yang menderita penyakit kronis seperti hipertensi ataupu diabetes mellitus yang periode pengobatanya cukup lama.

Diabetes mellitus (DM) atau dikenal juga dengan sebutan penyakit kencing manis merupakan salah satu penyakit kronis Pengelolaan DM memerlukan penanganan secara 
multidisplin yang mencakup non-obat dan terapi obat serta dilakukan secara terusmenerus. Kondisi ini membuat pasien DM menjadi bosan untuk meminum obat.

Pengobatan alternatif yang biasanya dilakukan oleh pasien DM adalah pemanfaatan obat herbal atau pengobatan tradisional. Menurut hasil penelitian yang dilakukan oleh Nani Cristiana mengenai analisis penggunaan obat herbal pada pasien diabetes meliitus di Surakarta diperoleh sebanyak 70,97\% pasien menggunakan obat herbal untuk pengobatan diabtes mellitus dalam penggunaan lebih dari 3 bulan. Penelitian ini bertujuan untuk mengetahui penggunaan obat herbal pada pasien diabetes mellitus serta mengetahui jenisjenis obat herbal atau obat tradisional yang digunakan pada pasien diabetes mellitus.

\section{METODE PENELITIAN}

Penelitian ini secara observatif non eksperimental untuk penggunaan obat herbal pada pasien diabetes mellitus serta mengetahui jenis-jenis obat herbal atau obat tradisional yang digunakan pada pasien diabetes mellitus. Lokasi yang digunakan dalam penelitian ini adalah di apotek rawat jalan RSUD A. W Sjahranie Samarinda Waktu penelitian berlangsung selama 1 bulan. sampel yang digunakan sejumlah 75 orang yang masuk kriteria inklusi dan ekslusi dari penelitian.

Kriteria inklusi:

1. Pasien Diabetes Mellitus Di Instalasi Rawat Jalan RS Abdul Wahab Sjahranie

2. Pasien Diabetes Mellitus yang mengonsumsi obat oral antidiabetik

3. Pasien Diabetes Mellitus yang telah mengalami komplikasi

\section{Kriteria Ekslusi}

1. Pasien Diabetes Mellitus yang dirawat Inap di RS Abdul Wahab Sjahranie

2. Pasien Diabetes Mellitus yang menggunakan injeksi insulin

Pada penelitian ini menggunakan alat bantu berupa kuisioner yang diberikan kepada pasien berupa daftar pertanyaan mengenai penggunaan obat herbal

\section{HASIL DAN PEMBAHASAN}

Penelitian kuantitatif, dilaksanakan selama bulan Okotober 2015 - November 2015 di Apotek Rawat Jalan RSUD A. W Sjahranie Samarinda

\section{Karakteristik responden}

Analisis ini bertujuan untuk mengetahui karakteristik responden (Umur, jenis kelamin, pekerjaan dan pendidikan). Berdasarkan lembar observasi yang telah diisi responden didapatkan hasil yaitu didapatkan data bahwa dari 60 responden, sebagian besar responden berusia 49-59 tahun yaitu sebanyak 26 pasien $(43,3 \%)$, sementara responden berusia $\geq 16-26$ tahun sebanyak 3 pasien $(5,0 \%)$, responden yang berusia 27-37 tahun sebanyak 3 pasien $(5,0 \%)$, responden yang berusia 38-48 tahun sebanyak 12 pasien $(20, \%)$, dan responden yang berusia $\geq 60$ tahun sebanyak 16 pasien $(26,7 \%)$.

Hasil penelitian menujukkan bahwa usia pasien berada pada masa dewasa akhir, dimana pada penelitian terlihat usia pasien yang menjadi subjek rata-rata berkisar 49-59 tahun, dimana diabetes mellitus tipe 2 meningkat seiring dengan bertambahnya usia. Penuaan sangat mempengaruhi banyak hormon untuk mengatur metabolisme tubuh, reproduksi dan fungsi tubuh lainnya. Penuaan mempengaruhi sensitivitas sel beta pankreas terhadap glukosa dan menunda pengambilan glukosa yang dimediasi oleh insulin (Wirawan, 2014). 
Tabel Distribusi Pasien Diabetes mellitus Berdasarkan Umur

\begin{tabular}{lll}
\hline Umur responden & Frekuensi (f)) & Persentase (\%) \\
\hline$\geq 16-26$ tahun & 3 & 5,0 \\
$27-37$ tahun & 3 & 5,0 \\
$38-48$ tahun & 12 & 20,0 \\
$49-59$ tahun & 26 & 43,3 \\
$\geq 60$ tahun & 16 & 26,7 \\
\hline Total & 60 & 100 \\
\hline
\end{tabular}

Tabel Distribusi Pasien Diabetes mellitus Berdasarkan Jenis Kelamin

\begin{tabular}{lcc}
\hline Jenis Kelamin & Frekuensi (f) & Persentase (\%) \\
\hline Laki-laki & 20 & 33,3 \\
Perempuan & 40 & 66,7 \\
\hline Total & 60 & 100 \\
\hline
\end{tabular}

Hasil menunjukkan bahwa jenis kelamin perempuan lebih banyak menderita diabetes mellitus dibandingkan dengan laki-laki. Dibuktikan dengan hasil dari penelitian ini, dimana pada perempuan sebanyak 40 pasien $(66,7 \%)$, sedangkan laki-laki sebanyak 20 pasien $(33,3 \%)$. Faktor yang dapat menyebabkan dominannya perempuan dari pada lakilaki adalah pada saat premenopause dan menopause, dimana kadar estrogen dan progesteron dalam tubuh yang semakin berkurang. Hormon estrogen berperan dalam membantu metabolisme lemak dan mengatur pola distribusi lemak di bawah kulit, sehingga ketika perempuan mengalami menopause terjadi penumpukan lemak yang beresiko terjadinya gangguan toleransi glukosa. Penumpukan lemak yang terjadi akan mengganggu kemampuan insulin untuk mempengaruhi pengambilan glukosa dan metabolisme yang sensitif terhadap insulin (resistensi insulin)

Tabel Distribusi Pasien Diabetes mellitus Berdasarkan Pendidikan

\begin{tabular}{lcc}
\hline Pendidikan & Frekuensi (f) & Persentase (\%) \\
\hline SD & 19 & 31,7 \\
SMP & 8 & 13,3 \\
SMA & 21 & 35,0 \\
Perguruan Tinggi & 12 & 20,0 \\
\hline Total & 60 & 100 \\
\hline
\end{tabular}

Hasil penelitian menunjukkan bahwa pasien diabetes mellitus terbanyak dengan pendidikan terakhir SMA sebanyak 21 pasien $(35,0 \%)$, SD sebanyak 19 pasien $(31,7 \%)$, perguruan tinggi sebanyak 12 pasien $(20,0 \%)$, dan SMP sebanyak 8 pasien $(13,3 \%)$. Hal ini tidak sesuai dengan teori dimana tingkat pendidikan dapat mempengaruhi kemampuan dan pengetahuan seseorang dalam menerapkan perilaku hidup sehat. Sehingga semakin tinggi tingkat pendidikan maka semakin tinggi pula kemampuan seseorang dalam menjaga gaya hidup dan semakin banyak pengetahuan yang dimiliki (Agrina, 2011). Tetapi hal ini tidak dapat dilihat dari satu faktor saja, banyak orang yang dengan tingkat pendidikan yang tinggi dan faktor ekonomi yang tinggi pula tetapi tidak bisa menjaga pola makan, yang 
cenderung lebih suka makanan yang siap saji, yang kaya akan kandungan lemak, gula, dan lain-lain. Faktor yang mempengaruhi lebih banyak pasien dengan tingkat pendidikan yang tinggi dan ekonomi yang tinggi pula tetapi tidak bisa menjaga pola makan yang baik adalah salah satunya dari faktor lingkungan dan aktifitas. Aktifitas yang begitu padat terkadang membuat pasien lupa dalam menjaga kesehatan tubuhnya, sehingga cenderung makan makanan yang instan dan tidak teratur. Selain itu faktor stress dapat meningkatkan kadar serotonin otak. Serotonin merupakan suatu neurottransmiter yang memiliki efek penenang sementara untuk meredakan stress, namun adanya faktor stress dapat memicu peningkatan kadar serotonin yang cenderung membuat seseorang mencari makanan yang manis dan berlemak tinggi

Tabel Distribusi Pasien Diabetes mellitus Berdasarkan Pekerjaan

\begin{tabular}{lcc}
\hline Pekerjaan & Frekuensi (f)) & Persentase (\%) \\
\hline IRT & 32 & 53,3 \\
Swasta & 1 & 1,7 \\
Wiraswasta & 9 & 15,0 \\
PNS & 15 & 25,0 \\
Pelajar & 3 & 5,0 \\
\hline Total & 60 & 100 \\
\hline
\end{tabular}

Penelitian ini pekerjaan responden cukup beragam yaitu ibu rumah tangga, swasta, wiraswasta, PNS dan pelajar. Sebagian besar responden adalah ibu rumah tangga yaitu 32 pasien $(53,3 \%)$. Sedangkan pekerjaan swasta hanya 1 pasien $(1,7 \%)$, pekerjaan wiraswasta sebanyak 9 pasien (15\%), PNS sebanyak 15 pasien $(25,0 \%)$, dan pelajar sebanyak 3 pasien $(5,0 \%)$. Identifikasi pekerjaan ini bertujuan untuk melihat tingkat aktifitas fisik. Karena sebagian besar responden adalah ibu rumah tangga, dengan aktifitas sehari-hari cukup aktif seperti membersihkan rumah dan memasak. Ibu rumah tangga yang memiliki aktifitas fisik dan pola gerak badan yang aktif merupakan salah satu faktor yang dapat mengendalikan kadar glukosa darah (Anggun, 2014). Kurangnya aktifitas fisik menjadi faktor resiko terjadinya resistensi insulin. Faktor lain yang mempengaruhi adalah usia, dimana usia subjek lebih banyak yaitu 49-59 tahun. Sehingga tidak dapat dipastikan bahwa subjek memiliki aktifitas yang aktif. Terlihat dari umur subjek yang tua, dimana penuaan mempengaruhi banyak hormon yang mengatur metabolisme, reproduksi, dan fungsi tubuh lain yang menyebabkan pasien mudah lelah, pusing, dan lain-lain. Penuaan mempengaruhi sensitivitas sel beta pankreas terhadap glukosa dan menunda pengambilan glukosa oleh insulin, sehingga tidak dapat banyak melakukan aktifitas.

\section{Profil Penggunaan Obat Herbal Pada Pasien Diabetes Mellitus}

Berdasarkan hasil penelitian menunjukan bahwa pasien diabetes mellitus meggunakan obat herbal antidiabetes sebanyak $60,32 \%$ bersamaan dengan obat antidiabetes (OAD). Hal ini menunjukan bahwa pasien diabetes mellitus sebagian besar melakukan swamedikasi dengan obat herbal yang digunakan bersamaan dengan obat antidiabetes (OAD) 


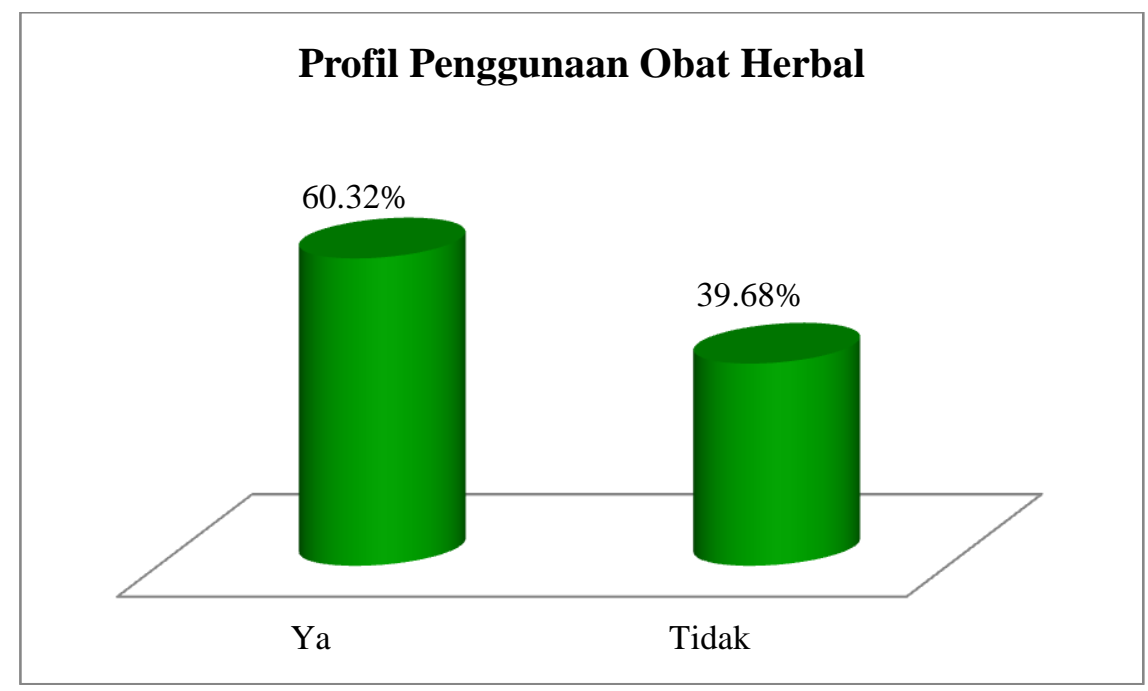

Diagram Penggunaan Obat Pada Pasien Diabetes Mellitus

\section{Profil Penggunaan Obat Herbal Menurut Jenis-Jenis Tanaman/obat Herbal}

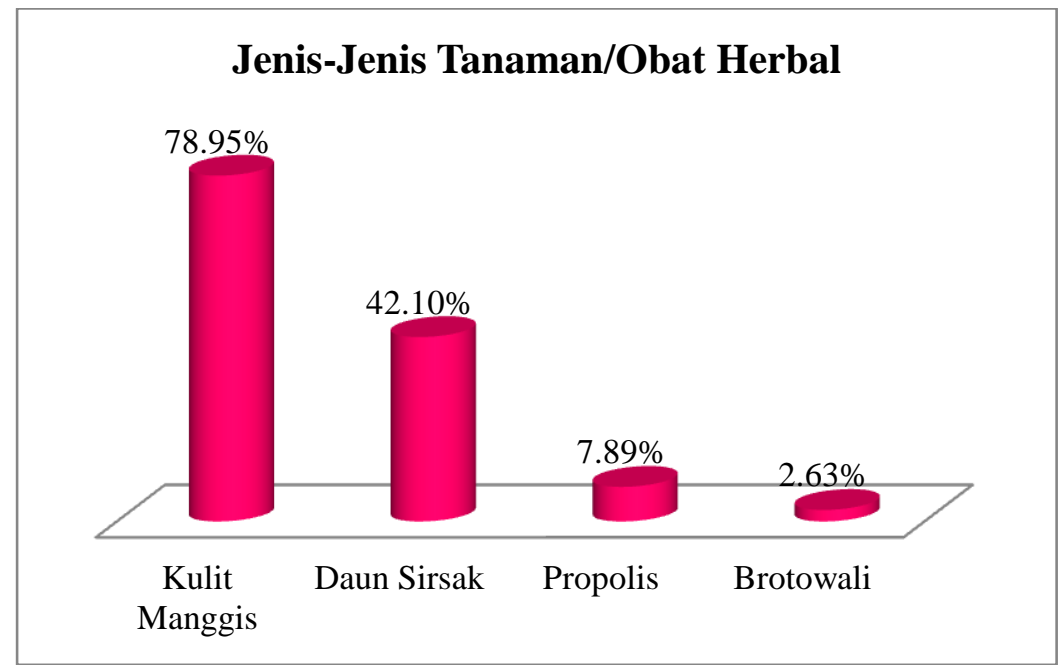

Diagram Jenis-jenis Tanaman/Obat Herbal Pada Pasien Diabetes Mellitus

Berdasarkan hasil penelitian, terdapat 3 jenis tanaman dan 1 produk herbal yang sering digunakan/dikonsumi oleh pasien diabetes mellitus. Dari 3 jenis tanaman tersebut dikonsumsi secara tunggal dan kombinasi. Mayoritas mengkonsumsi antidiabete herbal yang diolah sendiri melalui proses perebusan yang bahannya mereka cari dengan membeli dipasar atau mendapatkan dari pohon sekitar rumah dan tetangga. Hanya 1 jenis produk herbal yang digunakan yaitu propolis. 


\section{Profil Penggunaan Obat Herbal Menurut Penggunaan Dalam Sehari-hari}

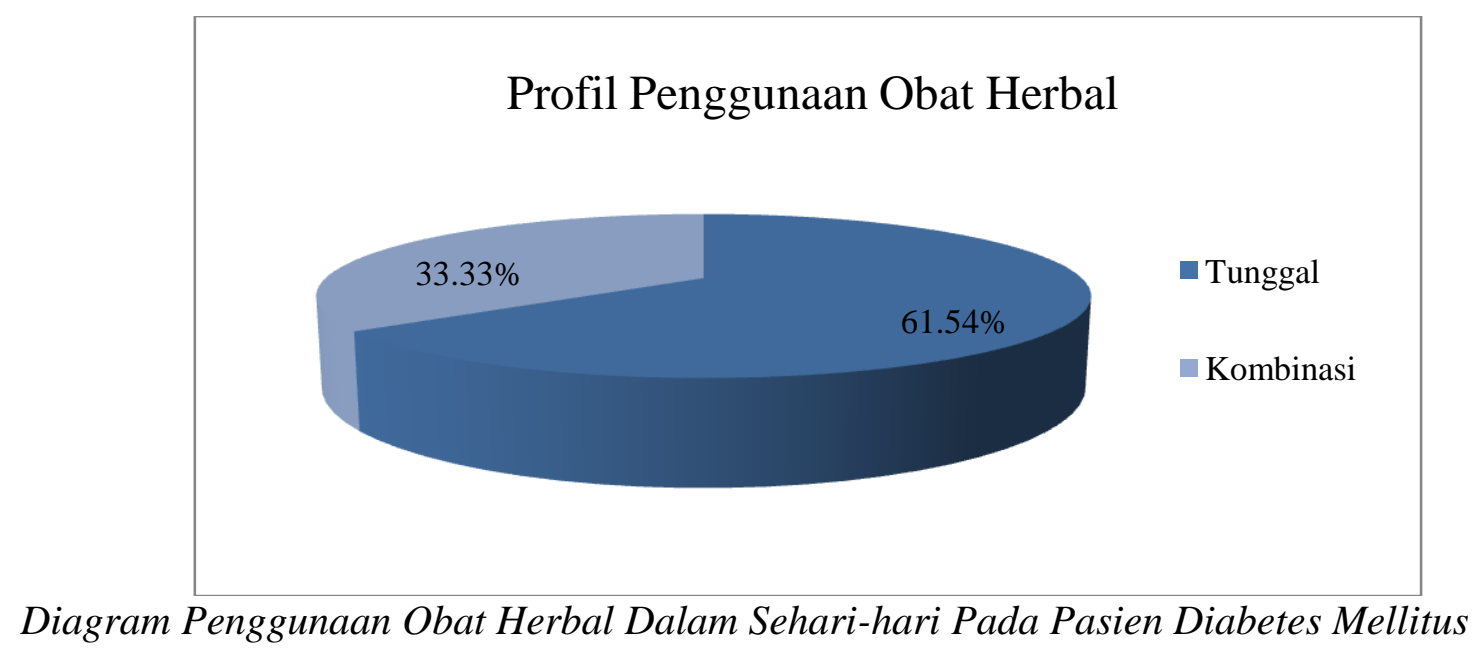

Berdasarkan hasil penelitian menunjukan bahwa penggunaan obat herbal antidiabetes digunakan tunggal sebanyak $61,54 \%$ dan kombinasi sebanyak 33,33\%. Penggunaan obat herbal antidiabetes ini digunakan juga bersamaan dengan obat antidiabetes (OAD).

\section{KESIMPULAN}

Karakteristik pasien diabetes mellitus di instalasi rawat jalan RSUD A.W.Sjahranie adalah $91,7 \%$ pada usia $36-60$ tahun, $66,7 \%$ perempuan, $35,0 \%$ pendidikan terakhir SMA, dan 53,3\% sebagai ibu rumah tangga. Penggunan obat herbal atau obat tradisional pada pasien diabetes melittus sebanyak $62.32 \%$ sebagai obat komplementer. Jenis-jenis obat herbal atau obat tradisional yang digunakan adalah kulit manggis sebanyak 78,95\%, daun sirsak sebanyak $42,10 \%$, propolis sebanyak $7,89 \%$, brotowali sebanyak $2,63 \%$.

\section{UCAPAN TERIMAKASIH}

Terimakasih kepada Pimpinan RSUD A.W Sjahranie Samarinda atas izin dan bantuan yang diberikan selama penelitian. Serta rekan-rekan di Apotek Rawat Jalan RSUD A.W Sjahranie Samarinda atas bantuan yang diberikan selama penelitian.

\section{DAFTAR PUSTAKA}

1. Direktorat Jendral Bina Kefarmasian Dan Alat Kesehatan Departemen Kesehatan RI. (2005). Pharmaceutical Care Untuk Penyakit Diabetes Mellitus. Jakarta

2. Direktorat Jendral Bina Kefarmasian Dan Alat Kesehatan Departemen Kesehatan RI. (2006). Pedoman Pelayanan Kefarmasian di Puskesmas. Jakarta

3. Mosihuzzaman, M., Choundhary, M.I. (2008). Protocols on Safety, Efficacy, Standardization, and Documentation pf Herbal Medicine. IUPAC Technical Report, 80, 2195-2230.

4. Nani C, 2011. Analisi Penggunaan Obat Herbal Pada Pasien Diabetes Mellitus Di Instalasi Rawat Jalan RSUD Dr. Moewardi Surakarta

5. Siti S, Yulfira M. 2003. Obat Tradisional Untuk Penyembuhan Penyakit Diabetes Mellitus Dari Pengobatan Tradisional (BATTRA) Di DKI Jakarta, Yogyakarta, Dan Surabaya. Jurnal Ekologi Kesehatan Vol 2 (2): 239-248 